\title{
Pengembangan model buku ajar digital keterampilan menyimak berdasarkan pendekatan autentik
}

\section{Handrianus Dwianot Momang}

Pendidikan Bahasa dan Sastra Indonesia, FKIP, Universitas Katolik Indonesia Santu Paulus Ruteng, Jln. Jend. A. Yani, No. I0, Ruteng, Manggarai, Nusa Tenggara Timur, Indonesia

rianmomang@unikastpaulus.ac.id

*Corresponding author: rianmomang@unikastpaulus.ac.id

\begin{tabular}{l}
\hline Sejarah Artikel Diterima: 25 Februari 202I Direvisi: 20 April 202I \\
ABSTRAK
\end{tabular}

\section{Kata Kunci Buku ajar digital, Keterampilan menyimak, Pendekatan autentik}

\section{ABSTRACT}

The learning needs of Listening Skills generally lead to the need for textbooks that accommodate materials, assignments and assessments. This situation allows researchers to develop listening textbooks with an authentic approach. This study aimed to produce a listening skill digital textbook model based on the authentic approach. This research employed R\&D. The development steps consisted of analysis of learning needs, product design, expert assessment, revision based on assessment results, field trials, final product revision. The data collection techniques used by researchers consisted of observation, document study, interviews, and questionnaires. The results showed that $(\mathrm{I})$ listening learning skills requires a textbook to accommodate the learning objectives, teaching materials, assignments, assessments, and media that can be used independently; (2) The developed product design refers to textbook anatomy and an authentic approach and uses the help of a flipbook maker application; (3) The results of the evaluation of content experts and media experts on the developed product fall into the "very good" category, with a mean of 3.62 from the content expert's assessment and a mean of 3.83 from the assessment of the media expert. (4) product revisions from content expert judgment leads to spelling errors, while product revisions from media expert judgment leads to audio control settings; 5) The results of field trials on students are in the "very good" category, with an average score of $3.4 ;(6)$ product revisions based on field trials lead to the use of cover images and color variations in textbooks. Based on the results obtained, the researcher has concluded that this research product is feasible and can be used as an alternative to textbooks in learning listening skills.

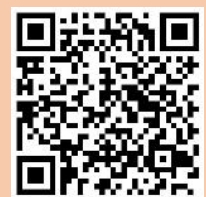

Copyright@202I, Handrianus Dwianot Momang This is an open access article under the CC-BY-3.0 license

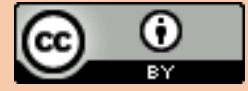

\begin{tabular}{ll}
\hline \hline Keywords & Digital textbook, Listening skills, Authentic approach, \\
\hline \hline How to Cite & Momang, H. D. (202I). Pengembangan model buku ajar digital keterampilan menyimak berdasarkan \\
& pendekatan autentik. KEMBARA: Jurnal Keilmuan, Bahasa, Sastra dan Pengajarannya (e-Journal), 7(I), \\
& 7I-93. doi: https://doi.org/I0.22219/kembara.v7iI.I6202 \\
\hline \hline
\end{tabular}




\section{PENDAHULUAN}

Menyimak merupakan salah satu keterampilan berbahasa yang berpengaruh pada kompetensi belajar seseorang. Hamouda, (20II) mengklaim bahwa dalam proses pembelajaran, kegiatan menyimak akan lebih dominan dilakukan jika dibandingkan dengan kegiatan membaca, berbicara dan menulis meskipun keempatnya terintegrasi satu sama lain. Dalam konteks pembelajaran bahasa, kegiatan menyimak dapat menjadi faktor kunci untuk keberhasilan akademik dan profesional. Hal ini dibuktikan penelitian Abdulrahman et al., (2018); Listiyaningsih, (2017); Tangkakarn \& Gampper, (2020); Tanrikulu, (2020) yang menunjukkan bahwa penyimak yang efektif cenderung lebih berhasil dalam pembelajaran. Dengan demikian, dapat diklaim bahwa keterampilan menyimak dapat menjadi faktor kunci kompetensi seseorang dalam pembelajaran di kelas.

Dalam memahami keterampilan menyimak, ada hal dasar yang perlu dibedakan antara kemampuan menyimak dan kemampuan mendengar. Hal ini disebabkan masih banyak yang beranggapan bahwa kegiatan mendengar dan menyimak melalui proses yang sama. Adapun perbedaan mendengar dan menyimak dapat dilihat dari sisi intensitasnya. Kegiatan mendengar tidak terlalu membutuhkan perhatian, sedangkan kegiatan menyimak membutuhkan perhatian dalam memahami apa yang disimaknya. Hal ini sejalan dengan persepsi menyimak yang berakar pada istilah yang mengandung arti perhatian, sedangkan untuk mendengar lebih berkaitan dengan persepsi suara dan kemampuan telinga (Worthington \& Bodie, 2018). Selain itu, (Rost, 2016) juga mengungkapkan bahwa perbedaan menyimak dan mendengar terletak pada tingkat niat. Tingkat niat dalam kegiatan menyimak lebih tinggi dibandingkan ketika mendengar.

Selanjutnya, perkembangannya konsep menyimak dalam pembelajaran tidak hanya merujuk pada pencapaian kompetensi kognitif seperti yang dikemukakan oleh beberapa pakar sebelumnya. Worthington \& Bodie (2018) menegaskan kembali bahwa menyimak merupakan keterampilan kompleks yang diakui sebagai (a) konstruksi multidimensional yang terdiri proses afektif, seperti termotivasi untuk memperhatikan orang lain; (b) proses perilaku, seperti menanggapi dengan umpan balik verbal dan nonverbal; dan (c) proses kognitif, seperti memperhatikan, memahami, menerima, dan menafsirkan konten dan pesan relasional. Berkaitan dengan itu, komponen sikap dalam menyimak termasuk dalam hal bagaimana pemelajar berpikir tentang kesenangan menyimak serta dapat memotivasi terhadap aktivitas tersebut. Perilaku menyimak mengarah pada tindakan seperti kontak mata, memberi dan menanggapi pertanyaan yang berfungsi untuk memberi sinyal perhatian dan minat kepada orang lain. Proses kognitif menyimak berupa proses-proses internal yang memungkinkan individu untuk hadir, memahami, menafsirkan dan mengevaluasi bahasa lisan yang disimak.

Kompleksitas keterampilan menyimak yang mengarah pada ranah pengetahuan, keterampilan, dan sikap seperti yang dijelaskan sebelumnya memang belum sepenuhnya dijumpai dalam proses pembelajaran di kelas. Hal ini dipengaruhi oleh beberapa hal seperti (I) kurangnya perhatian pada pengajaran keterampilan menyimak yang umumnya hanya terfokus pada keterampilan menulis, berbicara, dan membaca, (2) bahan dan media simakan yang digunakan, (3) sajian materi menyimak yang tidak terstruktur dan sebagainya (Mana et al., 2020; Prihatin, 2017; Sugiyono, 2014). Sejalan dengan beberapa masalah tersebut, peneliti juga mendapati beberapa kendala yang dihadapi oleh mahasiswa pada mata kuliah keterampilan menyimak. Masalah yang ditemukan terkait kompetensi mahasiswa yang lebih diarahkan pada pemahaman teoretis dan pengujian konsep tanpa mengarahkan atau melatih peserta didik untuk mengaplikasikan pemahamannya pada isu atau masalah yang dibahas dalam bahan simakan. Di sisi lain, mahasiswa juga terbatas menggunakan buku-buku referensi yang membantu pemahaman konseptual terkait keterampilan menyimak.

Dalam menanggapi dan mengatasi berbagai masalah menyimak tersebut, banyak peneliti dan ahli mulai mengeksplorasi dan menawarkan solusi pembelajaran keterampilan menyimak. Mulai dari alternatif metode pembelajaran (Doludea \& Nuraeni, 2018; Wiranty, 2019), penggunaan berbagai media pembelajaran menyimak (Made Darmayanti, 2018; Nurani et al., 2018; Soerraya \& Sriwulandari, 2019) hingga pengembangan bahan ajar keterampilan menyimak (Ernalis et al., 2016; Niarti et al., 
2017; Pujiatna et al., 2020; Sugiyono, 2014). Solusi-solusi ini pada dasarnya mengatasi persoalanpersoalan pembelajaran menyimak yang ditemukan dalam pembelajaran di tempat masing-masing.

Sama halnya dengan penelitian sebelumnya, tujuan penelitian ini mengarah pada solusi yang dapat digunakan untuk mengatasi permasalahan keterampilan menyimak, yakni dengan mengembangkan model buku ajar digital keterampilan menyimak berbasis pendekatan autentik. Pengembangan model buku ajar ini didasari oleh anatomi buku ajar yang mengakomodasi suplemen-suplemen inti sebuah pembelajaran seperti tujuan/capaian akhir, materi, tugas, penilaian dan perangkat tambahan lainnya. Arifin \& Kusrianto (2009) juga mengungkapkan bahwa kelebihan-kelebihan buku ajar dapat memberi kesempatan kepada peserta didik melatih kompetensi yang dipelajari dengan berbagai latihan-latihan yang mengarah pada pencapaian tujuan pembelajaran. Buku ajar juga disusun secara terstruktur yang memudahkan proses pemahaman peserta didik (Eriyanti, 2018; Mana et al., 2020; Puspitoningrum, 2015)

Selain kemasan yang berbeda, peneliti juga menggunakan pendekatan autentik untuk mengakomodasi keterampilan menyimak. Ancangan pendekatan ini mulanya muncul pada 1970an yang didasari orientasi komunikatif yang berkembang saat itu dalam pembelajaran bahasa. Idenya mengatakan bahwa "teks hidup", dan memberikan dampak langsung pada kompetensi bahasa karena terkait dengan kehidupan nyata peserta didik. Lombardi \& Oblinger (2007) lebih lanjut mengemukakan bahwa autentisitas dalam pembelajaran bahasa mengarah pada proses belajar yang berkelanjutan mengenai teksteks asli yang dipelajari, dan tugas-tugas yang diberikan baik dalam konteks pembelajaran maupun lingkup kehidupan sosial-budaya peserta didik. Tujuannya untuk mengembangkan kompetensi berbahasa yang secara langsung berpengaruh pada praktik-praktik penggunaan bahasa di kehidupan nyata (Ornellas et al., 2019; Roach et al., 2018).

Pendekatan autentik dalam pembelajaran keterampilan berbahasa pada dasarnya dapat diintegrasikan dalam capaian pembelajaran, materi, tugas atau latihan, dan sistem penilaian. Keempatnya saling berhubungan dan mendukung dalam mencapai target, atau tujuan pembelajaran. Hal ini juga sebelumnya sudah ditegaskan oleh Widharyanto (2016) yang mengungkapkan bahwa dalam pembelajaran bahasa Indonesia sifat-sifat autentik itu terkait secara parsial atau keseluruhan dengan: (I) teks atau materi yang dipelajari, (2) tugas-tugas pembelajaran beserta situasi sosial dan budaya yang mengiringinya, dan (3) bentuk-bentuk penilaian. Materi atau teks autentik merujuk pada teks yang diciptakan untuk memenuhi beberapa tujuan sosial dalam masyarakat, dirancang untuk menyampaikan pesan nyata, tidak dibuat untuk tujuan belajar bahasa dan dengan cara berbahasa yang digunakan dalam kehidupan peserta didik di luar kelas (Berardo, 2006; Jacobson et al., 2003; Lombardi \& Oblinger, 2007; Polio, 20I4). Materi autentik umumnya mengacu pada penggunaan pengajaran teks, foto, pilihan video, dan sumber pengajaran lainnya yang tidak disiapkan secara khusus untuk tujuan pedagogis.

Aspek selanjutnya yang berpengaruh dalam penggunaan pendekatan autentik ialah tugas autentik. Pemerian tugas autentik dalam pembelajaran berbahasa merupakan wujud dan strategi dalam melatih keterampilan berbahasa peserta didik yang dapat diimplementasikan secara berkelanjutan. Hal ini mengingat bahwa sebuah tugas bersifat autentik jika menyangkut relevansi dunia nyata dan harus mempertimbangkan kelayakan dan keberlanjutan tujuan belajar saat digunakan (Mishan, 2004). Selanjutnya, Widharyanto (2016) mengemukakan bahwa terdapat empat tipe tugas pembelajaran yang bisa terjadi, yakni (I) aktivitas berupa penugasan grammatical content dan lexical content yang lepas konteks, (2) aktivitas berupa penugasan grammatical content dan lexical content dalam konteks pemakaian wacana, (3) aktivitas berupa performansi siswa di kelas namun bersifat simulatif, dan (4) aktivitas berupa performansi aktual siswa dalam konteks situasi sosial budaya sesungguhnya di masyarakat. Keempat tipe tugas autentik ini memiliki tingkat autentisitas yang berbeda-beda

Aspek lainnya dalam pendekatan autentik ialah penilaian autentik. Nurgiyantoro, (2013) mengungkapkan bahwa penilaian autentik menekankan pengukuran hasil pembelajaran yang berupa kompetensi peserta didik untuk melakukan sesuatu, bukan sekadar mengetahui sesuatu sesuai dengan bidang dan kompetensi yang ingin dicapai. Lebih lanjut, pakar ini mengemukakan empat tipe penilaian

Handrianus Dwianot Momang, Pengembangan model buku ajar digital keterampilan menyimak berdasarkan pendekatan autentik 
autentik antara lain penilaian kinerja, portofolio, proyek, dan evaluasi diri. Keempat bentuk tipe penilaian ini dapat menjadi alat pengukur ketercapaian tujuan peserta didik di kelas.

Selain beberapa hal yang telah dijelaskan sebelumnya, hal baru yang ditawarkan dalam penelitian ini terkait pemanfaatan aplikasi flipbook maker yang mampu memberi variasi baru dalam pembelajaran keterampilan menyimak. Penggunaan flipbook maker sejauh eksplorasi peneliti belum pernah digunakan khusus dalam pembelajaran keterampilan berbahasa. Fungsi aplikasi ini pada dasarnya digunakan untuk mendigitalisasi buku-buku yang umumnya terkesan kaku dan monoton. Selain itu, aplikasi ini juga dibekali dan dukung oleh fitur-fitur multimedia penggunaannya (seperti teks, gambar, animasi, audio, video, dan tautan interaktif) yang menambah variasi penyajian konten pembelajaran, mempermudah akses sumber belajar dan latihan, menarik dan praktis digunakan. Dengan begitu, peserta didik dapat mengontrol cara belajar mereka masing-masing serta mendukung pembelajaran keterampilan menyimak yang membutuhkan konten atau bahan simakan lisan.

Berdasarkan uraian di atas, peneliti mengharapkan agar sekiranya kajian dan produk penelitian pengembangan ini memberi kontribusi kepada penggunanya. Dari sisi keilmuan, hasil kajian penelitian dan pengembangan ini dapat dijadikan acuan dalam penelitian lanjutan, baik dari aspek keterampilan berbahasa lainnya (membaca, menulis maupun berbicara), pendekatan pembelajaran yang digunakan, maupun pengembangan buku ajar lainnya. Di sisi lain, produk model buku ajar ini sekiranya dapat dimanfaatkan atau dijadikan acuan utama dalam pembelajaran keterampilan menyimak, baik itu mahasiswa maupun dosen pengampu mata kuliah.

\section{METODE}

Penelitian ini termasuk dalam desain penelitian pengembangan (Research and Development). Adapun prosedur penelitian yang dilakukan terdiri dari tahap (I) analisis kebutuhan pembelajaran, (2) desain produk, (3) penilaian ahli, (4) revisi berdasarkan hasil penilaian, (5) uji coba lapangan, (6) revisi buku ajar final. Tahap-tahap tersebut merupakan hasil modifikasi dari model pengembangan Dick \& Carey, Borg \& Gall, dan Sugiono. Modifikasi tahapan model pengembangan ini karena ada beberapa tahap dalam ketiga model pengembangan tersebut yang relevan dan tidak relevan untuk digunakan dalam penelitian pengembangan ini. Banyak penelitian pengembangan sebelumnya juga memodifikasi model-model-model pengembangannya sesuai karateristik penelitian masing-masing (Erika, 2019; Friston et al., 2020; Mulyaningtyas, 2020; Rahmayantis, 2016; Suryanto, 2016). Senada dengan itu, Borg \& Gall, (1983) juga mengemukakan bahwa peneliti dimungkinkan untuk membatasi penelitian dalam skala kecil, termasuk membatasi langkah penelitian.

Desain uji coba produk pengembangan ini melalui dua tahap. Tahap pertama yaitu tahap penilaian ahli yang dilakukan oleh ahli dalam menilai produk pengembangan. Tahap kedua melalui uji coba lapangan yang akan diikuti oleh mahasiswa. Adapun subjek uji coba terdiri dari satu orang ahli isi pembelajaran keterampilan menyimak, satu orang ahli media pembelajaran dan 57 mahasiswa aktif yang mengikuti pembelajaran keterampilan menyimak.

Teknik pengumpulan data yang digunakan berupa observasi (non partisipan), studi dokumen, wawancara dan penyebaran angket. Bertalian dengan teknik pengumpulan data, instrumen yang digunakan berupa lembar observasi, lembar studi dokumen, pedoman wawancara dan lembar angket. Adapun teknik analisis data yang digunakan terdiri dari teknik analisis data kualitatif Miles dan Huberman dan teknik Weigh Mean Skor untuk menganalisis data kuantitatif yang diperoleh dari penyebaran angket.

\section{HASIL DAN PEMBAHASAN}

Penelitian pengembangan ini menghasilkan produk berupa buku ajar digital keterampilan menyimak berbasis pendekatan autentik. Adapun hasil dan pembahasan penelitian pengembangan ini sebagai berikut. 


\section{Kebutuhan Pembelajaran Keterampilan Menyimak}

Analisis kebutuhan, dan penemuan masalah dalam pembelajaran merupakan tahap awal dalam penelitian ini. Tahap ini pada dasarnya merupakan integrasi dari tahap pertama model pengembangan Borg and Gall (Borg \& Gall, I983) yakni penelitian dan pengumpulan informasi (spt. kajian pustaka dan pengamatan kelas) dan tiga tahap pengembangan model Dick and Carey (Dick \& Carey, I996) yakni mengidentifikasi tujuan umum pembelajaran, menganalisis pembelajaran, dan mengidentifikasi tingkah laku dan karakteristik siswa. Bertalian dengan tahap ini, peneliti menggunakan teknik pengumpulan data berupa observasi non partisipan, studi dokumen, wawancara (tidak terstruktur), dan penyebaran angket untuk mengidetifikasi kebutuhan mahasiswa.

Adapun hasil analisis data observasi selama 3 pertemuan pada dua kelas yang berbeda menunjukkan bahwa masalah pembelajaran menyimak mengarah pada (I) belum tersedianya variasi materi, tugas dan sistem penilaian yang belum jelas, (2) tidak tersedianya buku acuan utama yang digunakan mahasiswa, dan (3) media pembelajaran yang digunakan sangat monoton. Sementara itu, data studi dokumen diperoleh dari kajian dokumen-dokumen pembelajaran keterampilan menyimak seperti Rencana Pembelajaran Semester (RPS), Rancangan Tugas Perkuliahan (RTP), rubrik penilaian dan bahan ajar, hasil tugas mahasiswa dan sumber rujukan yang digunakan. Hasil temuan dalam studi dokumen menunjukkan bahwa (I) terdapat ketidaksesuaian antara tujuan pembelajaran dan pengalaman belajar, (2) rancangan tugas yang lebih mengarah pada kompetensi kognitif terkait pengetahuan konseptual menyimak (3) ketersediaan rubrik penilaian yang mengakomodasi segala latihan, dan tugas yang diberikan, dan (4) sumber referensi yang belum diperbaharui. Masalah-masalah yang telah diidentifikasi ini umumnya mengacu pada dua masalah yang sama dengan temuan sebelumnya terkait media pembelajaran (Made Darmayanti, 2018; Nurani et al., 2018; Soerraya \& Sriwulandari, 2019) dan bahan ajar menyimak (Ernalis et al., 2016; Niarti et al., 2017; Pujiatna et al., 2020; Sugiyono, 20I4).

Di samping itu, peneliti juga melakukan wawancara kepada dosen pengampu dan kaprodi serta menyebarkan angket kepada mahasiswa untuk mengonfirmasi hasil pengamatan, dan studi pustaka, sekaligus mengidentifikasi kebutuhan pembelajaran menyimak. Berdasarkan hasil wawancara, peneliti menyimpulkan bahwa secara umum kebutuhan pembelajaran keterampilan menyimak terdiri dari kebutuhan buku ajar dan media pembelajaran yang didasari pada pembaharuan rancangan materi, tugas dan penilaian serta media yang dapat diakses dengan mudah sebagai sumber acuan pembelajaran. Sementara itu, kebutuhan mahasiswa dari hasil penyebaran angket juga menunjukkan bahwa pembelajaran keterampilan menyimak membutuhkan buku pegangan yang mengakomodasi isu dan masalah di kehidupan nyata, serta media pembelajaran yang dikemas dengan menarik dan mengakomodasi berbagai bentuk bahan simakan seperti gambar, animasi, audio maupun video.

Berdasarkan hasil identifikasi masalah dan kebutuhan pembelajaran keterampilan menyimak, peneliti mencoba merancang model buku ajar digital keterampilan menyimak dengan pendekatan autentik. Adapun isi dari model buku ajar yang dikembangkan memuat tujuan pembelajaran, materi yang sesuai dengan kehidupan nyata di masyarakat, latihan dan tugas beserta kriteria penilaiannya. Selain itu, kemasan dari model buku ajar ini dirancang secara digital dengan memaksimalkan aplikasi dan sumber bahan simakan yang dapat berkontribusi pada peningkatan kompetensi mahasiswa.

\section{Desain Produk}

Tahap desain produk merujuk pada tahap perancangan dan pengembangan produk penelitian berdasarkan hasil identifikasi masalah, dan kebutuhan pembelajaran keterampilan menyimak. Tahap ini pada dasarnya mengkolaborasikan tahap ketiga model Borg and Gall (Borg \& Gall, I983) yakni mengembangkan bentuk awal produk (seperti materi, dan bentuk evaluasi), dan empat tahap model Dick dan Carey (Dick \& Carey, 1996) yakni merumuskan tujuan kinerja, mengembangkan instrumen penilaian, mengembangkan strategi pengajaran, serta mengembangkan dan memilih materi pembelajaran. Tahap-tahap dalam desain produk ini kemudian dirancang dalam model buku ajar dengan menempatkannya sesuai dengan anatomi penulisan buku ajar. Adapun anatomi buku ajar menurut 
Arifin \& Kusrianto (2009) memuat empat bagian yang terdiri dari bagian luar buku (sampul depan, punggung, belakang), bagian depan buku ajar (halaman judul buku, halaman hak cipta, halaman kata pengantar halaman daftar isi, dan halaman pendahuluan), bagian isi buku ajar (judul bab, deskripsi singkat bab, capaian pembelajaran, isi materi, aktivitas dan latihan beserta rubrik penilaiannya, rangkuman materi, tugas lanjutan beserta kriteria penilaiannya), bagian pasca isi (berisi halaman daftar pustaka, glosarium halaman biografi penulis).

Terkait dengan beberapa hal di atas, peneliti mendesain produk awal dengan memperhatikan substansi dari tahap-tahap yang digunakan serta mengacu pada anatomi buku ajar. Adapun draf isi dari model buku ajar yang dikembangkan peneliti dapat dilihat pada Tabel I.

Tabel I

Rincian Isi Model Buku Ajar

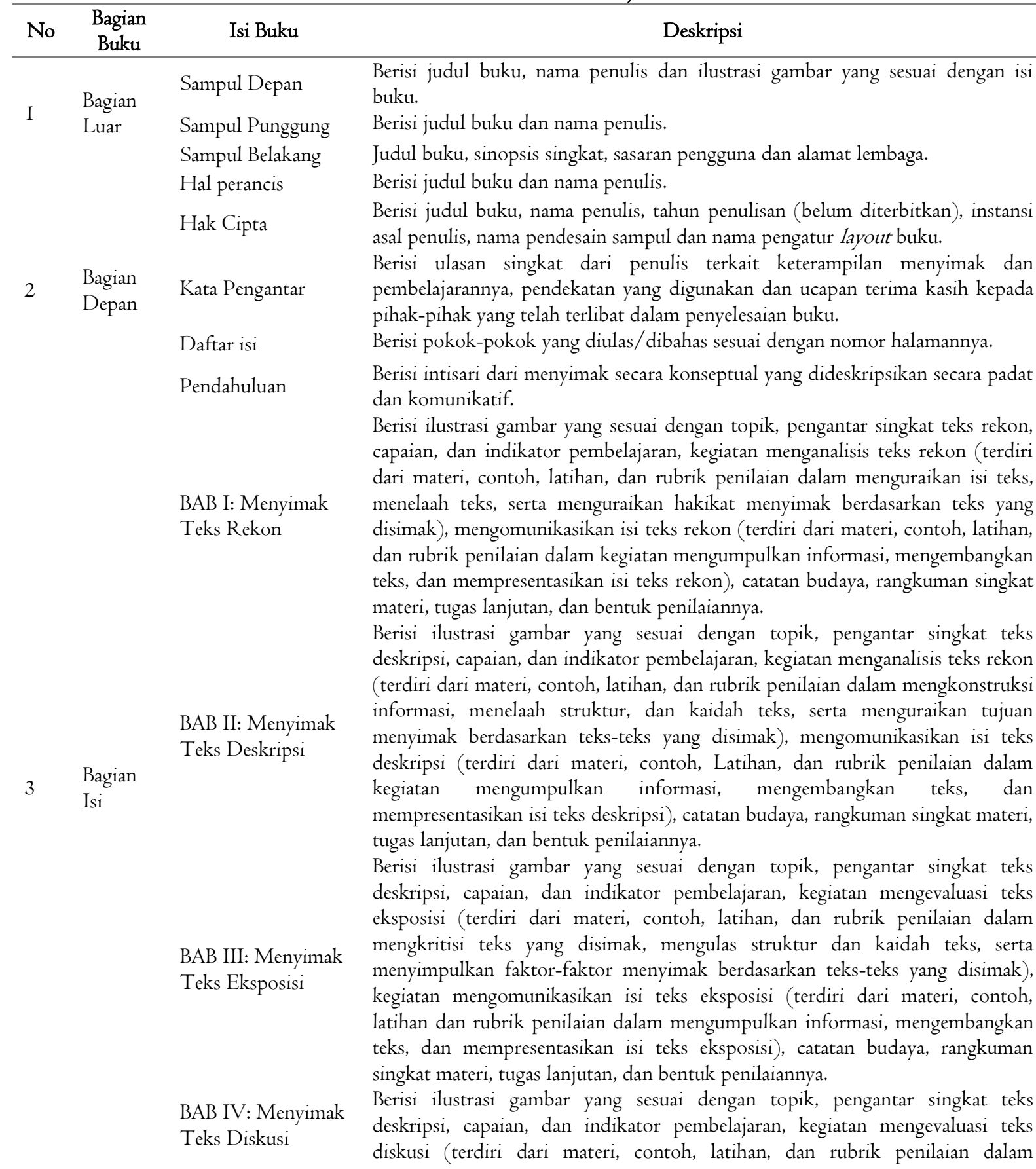


BAB V: Menyimak Teks Prosedur

BAB VI: Menyimak Teks Berita

$\begin{array}{lll}4 & \text { Bagian } & \text { Daftar Pustaka } \\ & \text { Penutup } & \text { Glosarium } \\ & & \text { Biodata Penulis }\end{array}$

mengkritisi argumen pro dan kontra dalam teks yang disimak, mengulas struktur, dan kaidah teks, serta menyimpulkan strategi-strategi menyimak dalam menyimak teks diskusi), kegiatan mengomunikasikan isi teks diskusi (terdiri dari materi, contoh, latihan, dan rubrik penilaian dalam mengumpulkan informasi, mengembangkan teks, dan mempresentasikan isi teks diskusi), catatan budaya, rangkuman singkat materi, tugas lanjutan, dan bentuk penilaiannya.

Berisi ilustrasi gambar yang sesuai dengan topik, pengantar singkat teks deskripsi, capaian, dan indikator pembelajaran, kegiatan menciptakan teks diskusi (terdiri dari materi, contoh, latihan dan rubrik penilaian dalam mereparasi teks, mengkreasi teks sesuai struktur dan kaidah kebahasaan, serta merancang teks prosedur dengan melibatkan tahap-tahap pembelajaran menyimak), kegiatan mengomunikasikan isi teks prosedur (terdiri dari materi, contoh, latihan dan rubrik penilaian dalam mengumpulkan informasi, mengembangkan teks, dan mempresentasikan isi teks diskusi), catatan budaya, rangkuman singkat materi, tugas lanjutan, dan bentuk penilaiannya.

Berisi ilustrasi gambar yang sesuai dengan topik, pengantar singkat teks deskripsi, capaian, dan indikator pembelajaran, kegiatan menciptakan teks diskusi (terdiri dari materi, contoh, latihan, dan rubrik penilaian dalam mengabstraksi teks, mengkreasi teks sesuai struktur, dan kaidah kebahasaan, serta merumuskan isi berita dengan menggunakan berbagai jenis/ragam menyimak), kegiatan mengomunikasikan isi teks prosedur (terdiri dari materi, contoh, latihan, dan rubrik penilaian dalam mengumpulkan informasi, mengembangkan teks, dan mempresentasikan isi teks diskusi), catatan budaya, rangkuman singkat materi, tugas lanjutan, dan bentuk penilaiannya.

Berisi daftar referensi atau rujukan yang digunakan dalam buku ajar dengan sistem penulisan menggunakan format APA.

Berisi daftar istilah yang terdapat dalam buku ajar.

Berisi informasi singkat terkait latar belakang pendidikan penulis.

Penyajian buku ajar menyimak pada Tabel I di atas pada dasarnya mengadopsi siklus pembelajaran dalam pendekatan berbasis genre (GBA). Siklus pembelajaran ini terdiri dari tiga tahap antara lain tahap pemodelan teks, tahap konstruksi bersama dan tahap konstruksi mandiri (Dirgeyasa, 2016). Penggunaan siklus pembelajaran ini dalam buku ajar bertujuan untuk mensistematisasi kegiatan pembelajaran menyimak, serta cara belajar peserta didik terhadap topik yang dibahas. Selain itu, melalui tahap-tahap dalam siklus ini, peserta didik diarahkan untuk mampu belajar secara otonom dan menguasai hal-hal utama dari konten-konten yang dipelajari seperti konteks, bentuk, dan aspek kebahasaan (Gay et al., 2018; Tuan, 20I I).

Selanjutnya, dalam rangka mengaktualisasi isi buku dengan ancangan pendekatan autentik, peneliti menggunakan 4C yang ditawarkan Coyle et al. (20I0) dalam CLIL yakni content, communication, cognition, dan culture. Content atau materi berkaitan dengan topik tertentu yang dibahas misalnya sosial, politik, budaya. Communication atau komunikasi berkaitan dengan ragam atau kaidah bahasa yang digunakan termasuk struktur atau pola penyampaiannya misalnya membandingkan, melaporkan. Cognition atau kognisi berkaitan dengan kompetensi menyimak yang ingin dicapai misalnya menganalisis atau mengevaluasi. Culture atau budaya berkaitan dengan muatan lokal lingkungan sekitar yang berkaitan dengan topik yang dibahas. Keempat hal pokok ini sebelumnya telah membawa pengaruh yang signifikan terhadap kompetensi peserta didik seperti (I) lebih termotivasi untuk terlibat secara aktif dan sukarela dalam menggunakan bahasa target yang dipelajari, (2) terampil berkomunikasi menggunakan bahasa target, (3) meningkatkan kecakapan berbahasa yang meliputi empat keterampilan berbahasa dan (4) termotivasi menguasai berbagai budaya dan nilai-nilai kemanusiaan (Breidbach \& Viebrock, 2012; Cinganotto, 2016; Ellison, 2019). Sejalan dengan itu, penerapan 4C dalam buku ajar ini diharapkan mampu memfasilitasi berbagai kompetensi menyimak mahasiswa baik dalam kelas maupun dalam lingkup sosial budaya di masyarakat.

Di sisi lain, ancangan pendekatan autentik dalam pengembangan model buku ajar terfokus pada

Handrianus Dwianot Momang, Pengembangan model buku ajar digital keterampilan menyimak berdasarkan pendekatan autentik 
empat suplemen pembelajaran yang terdiri dari capaian dan indikator pembelajaran, materi ajar, tugas, dan penilaian. Pada perumusan tujuan pembelajaran, ancangan pendekatan autentik mengarah pada perumusan kompetensi peserta didik yang akan diaktualisasi secara nyata di luar kelas. Di samping itu, proses perumusan capaian pembelajaran dan indikator pembelajaran juga didasari temuan masalah sebelumnya serta mengacu pada panduan penyusunan CP Dirjen Kemenristek Dikti tahun 2016. Dalam setiap topik pembelajaran peneliti merumuskan capaian pembelajaran dengan mengintegrasikan taksonomi kognitif Bloom revisi Anderson dan Krathwohl (Anderson et al., 200I) untuk aspek pengetahuan (tahap menganalisis/C4 hingga menciptakan/C6), taksonomi keterampilan abstrak (Dyer et al., 20II) untuk aspek keterampilan (tahap mengumpulkan informasi/P3 hingga mengomunikasikan/P5), dan taksonomi afektif Krathwohl (Bloom et al., 1956) untuk aspek sikap (tahap merespon/AI hingga mengamalkan/A5). Setiap capaian pembelajaran ini kemudian dipecah lagi menjadi beberapa indikator pembelajaran yang mengacu pada penggunaan $\mathrm{KKO}$ yang selevel dengan tingkatan capaian pembelajaran.

Selanjutnya peneliti merancang penyajian materi autentik dengan mengacu pada capaian, dan indikator pembelajaran. Penyajian materi autentik dalam buku ajar lebih mengarah pada materi atau konten-konten yang diambil dari rekaman suara atau video dari stasiun radio dan televisi (lisan) dan sebagian kecil dari surat kabar (tertulis) yang kredibel tanpa mengalami proses modifikasi substansi. Widharyanto (2016) mengemukakan bahwa materi yang diambil dari teks yang ada dalam komunikasi sehari-hari tanpa mengalami modifikasi sama sekali memiliki tingkat autentisitas yang lebih tinggi. Penyajian materi juga mengakomodasi pengetahuan konseptual terkait menyimak yang disajikan secara runtut dan memiliki relevansi dengan topik, dan teks yang dibahas.

Perancangan tugas autentik pada dasarnya tidak hanya mengacu pada capaian pembelajaran tetapi disesuaikan juga dengan materi yang dipelajari. Penempatan latihan, dan tugas autentik dalam buku ajar sangat bervariasi, dan tidak terpaku pada urutan penyajian materi. Adapun tipe-tipe tugas autentik yang diakomodasi dalam buku ajar terdiri dari (I) aktivitas berupa penugasan grammatical content, dan lexical content yang lepas konteks, (2) aktivitas berupa penugasan grammatical content, dan lexical content dalam konteks pemakaian wacana, (3) aktivitas berupa performansi siswa di kelas namun bersifat simulatif, dan (4) aktivitas berupa performansi aktual siswa dalam konteks situasi sosial budaya sesungguhnya di masyarakat (Widharyanto, 2016). Tipe tugas I, 2, dan 3 difokuskan pada kegiatan pembelajaran di kelas dengan porsi yang berbeda-beda sedangkan tugas tipe 4 dirancang sebagai tugas tambahan di luar kelas. Hal ini bertujuan agar gagasan dan keterampilan yang dipelajari di kelas dapat ditindaklanjuti dalam situasi nyata di masyarakat. Dengan demikian, peserta didik tidak hanya belajar untuk keperluan akademis semata, tetapi mampu mengaplikasikannya dalam kehidupan sosial bermasyarakat di kehidupan masing-masing.

Berbeda dengan penyajian tugas, penilaian autentik dalam buku ajar disajikan setelah pemerian tugas. Hal ini dimaksudkan agar setiap tugas yang dikerjakan mahasiswa dapat mengacu pada rubrik penilaiannya. Hal ini senada dengan salah satu wujud manfaat penilaian autentik yang dikemukakan Itaristanti (2016) mengenai penggunaan penilaian autentik memungkinkan dilakukannya pengukuran secara langsung terhadap kinerja mahasiswa sebagai indikator capaian kompetensi yang pelajari. Selain itu, sajian penilaian jelas dalam pembelajaran dapat mengatasi berbagai hasil dalam suatu tugas (Mishan, 2004). Adapun tipe penilaian yang digunakan terdiri dari penilaian kinerja, penilaian proyek dan evaluasi diri yang tergambar dalam wujud rubrik holistik dan rubrik analitik dalam buku ajar.

Setelah draf buku ajar selesai, peneliti selanjutnya melakukan proses digitalisasi buku ajar dengan bantuan aplikasi flipbook Maker. Proses digitalisasi ini pada dasarnya mengubah tampilan, dan akses penggunaannya. Selain itu, beberapa elemen multimedia seperti teks (tertulis), gambar, animasi, audio, video, dan tautan interaktif dapat dikombinasikan, sehingga buku ajar terlihat lebih hidup dan menarik. Elemen-elemen ini merupakan elemen dasar yang sudah disediakan oleh aplikasi dan peneliti hanya memodifikasinya sesuai dengan kebutuhan-kebutuhan pembelajaran. Berikut tampilan awal desain buku ajar digital dengan aplikasi flipbook maker. 


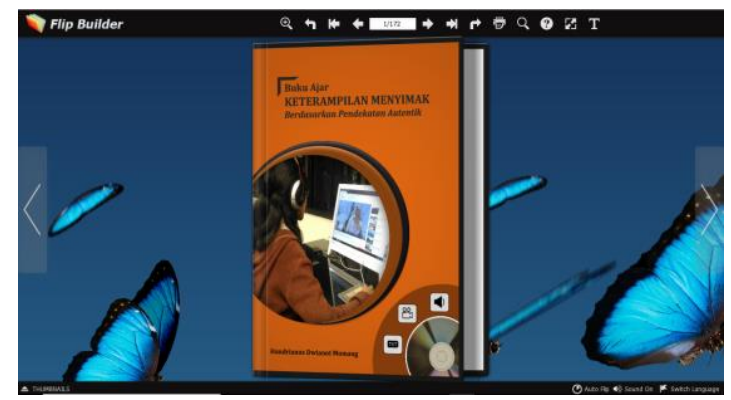

Gambar I.Tampilan Awal Buku Ajar Digital

Pertama, elemen teks. Teks merupakan salah satu komponen multimedia dalam penyampaian informasi tulis. Penggunaan teks dalam multimedia dapat ditemukan pada judul menu, sub-menu, dan tombol (Vaughan, 2006). Dalam model buku ajar ini, penggunaan teks tidak hanya terbatas pada judul, sub-menu dan tombol saja tetapi digunakan pula untuk menjelaskan atau mendeskripsikan hal-hal utama terkait topik yang dibahas. Sama halnya dengan buku-buku pelajaran cetak yang umumnya dijumpai sebelumnya.

Kedua, elemen gambar. Gambar dapat dikatakan sebagai tampilan visual yang statis dan memiliki informasi atau pesan tertentu. Penggunaan elemen gambar dalam produk penelitian ini dikhususkan untuk menambah variasi tampilan, pengantar topik, dan stimulus untuk menarik pengetahuan awal sebelum memulai pembahasan materi topik. Berikut tampilan salah satu bentuk elemen gambar dalam buku ajar digital ini.

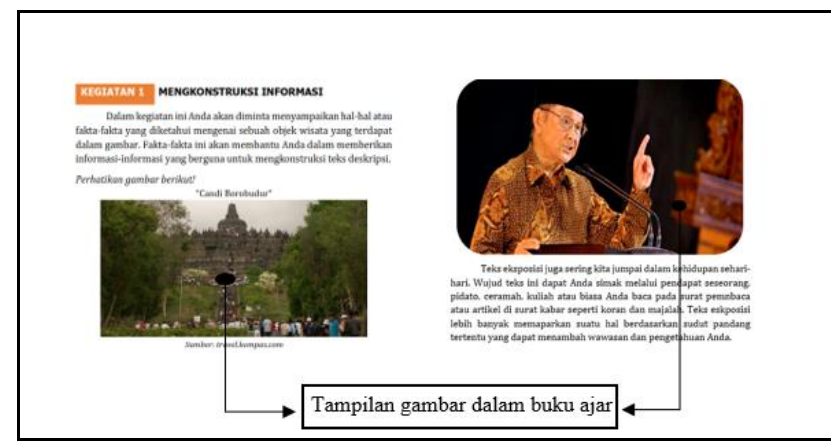

Gambar 2. Tampilan Gambar dalam Buku Ajar Digital

Ketiga, elemen animasi. Animasi yang terdapat dalam produk ini berupa animasi perpindahan halaman buku dan animasi latar buku. Animasi dalam produk ini bertujuan untuk memberi variasi dan daya tarik secara visual kepada penggunanya. Berikut contoh gambar dari bentuk animasi yang terdapat dalam produk buku ajar ini.

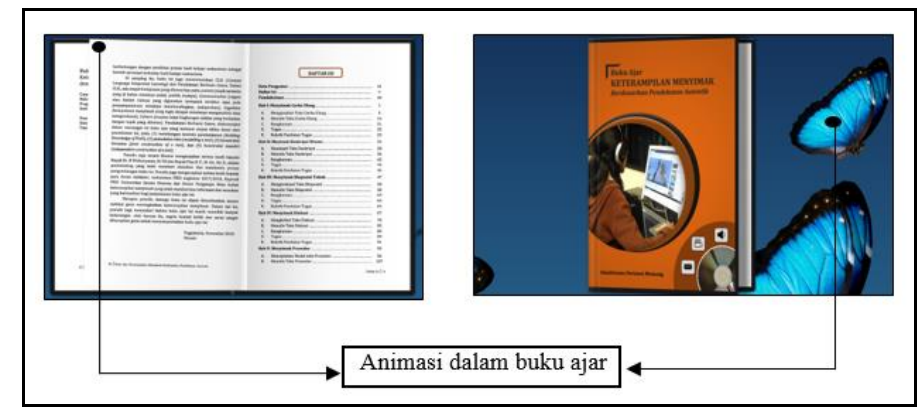

Gambar 3. Tampilan Animasi dalam Buku Ajar Digital 
Keempat, elemen audio. Audio sebagai bahan simakan utama dalam pembelajaran keterampilan menyimak membawa dampak pada kompetensi menyimak. Selain itu, pembelajaran menyimak yang menggunakan media audio diklaim lebih unggul dibandingkan dengan yang tidak menggunakannya (Yusantika et al., 2018). Dalam produk ini, audio yang digunakan berupa rekaman suara yang diambil dari sumber-sumber kredibel tanpa modifikasi sesuai dengan topik yang dibahas. Sistem penggunaannya dirancang sederhana mungkin untuk memudahkan pengguna mengakses audio simakan dalam produk ini yak dengan cara meneka ikon audio untuk memulai atau mengakhiri simakan. Berikut contoh tampilan audio yang terdapat dalam produk ini.

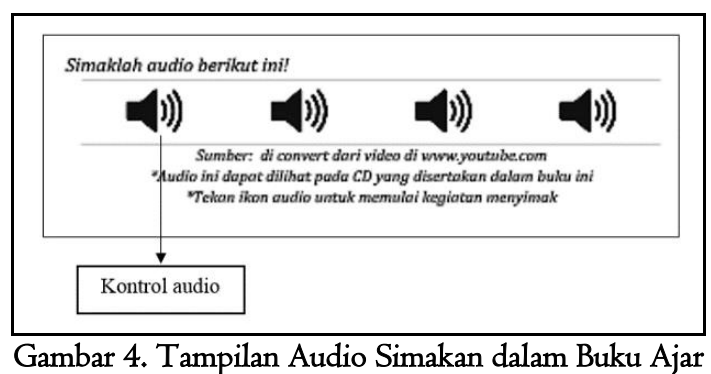

Kelima, elemen video. Selain audio, bahan simakan yang disuguhkan dalam buku ajar ini juga berupa video. Video-video yang disuguhkan dalam buku ajar elektronik ini merupakan video-video yang pada umumnya berupa rekaman tayangan program televisi Indonesia tanpa modifikasi. Video simakan yang terdapat dalam buku ajar ini juga dapat dikontrol dengan mudah oleh pengguna, baik dari sisi ukuran, durasi dan volume suara. Berikut contoh gambar video yang terdapat dalam buku ajar keterampilan menyimak yang dikembangkan peneliti.

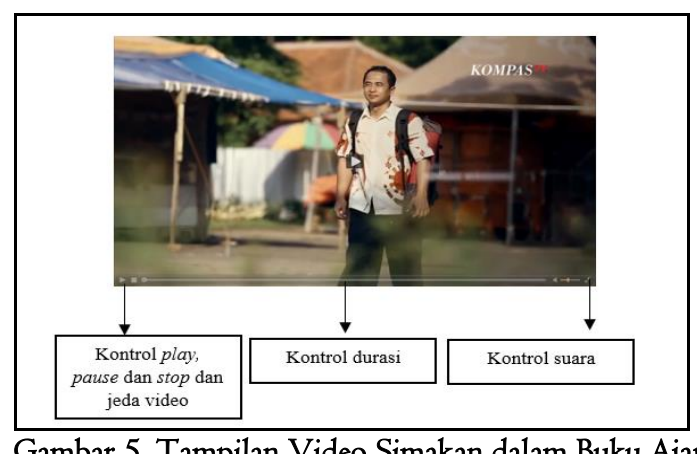

Keenam, elemen tautan interaktif. Tautan interaktif ini dapat pengguna temukan pada beranda layar aplikasi dan daftar isi. Tautan interaktif ini dalam produk ini dimaksudkan untuk mempermudah pengguna mengakses produk atau menemukan bab/subbab yang ingin dicari atau dipelajari tanpa membuka satu per-satu halaman. Sistem penggunaannya dengan cara menekankan mouse, keyboard atau objek, sehingga menyebabkan program melakukan perintah tertentu sesuai yang diinginkan. Berikut contoh gambar tautan interaktif yang terdapat dalam buku ajar. 


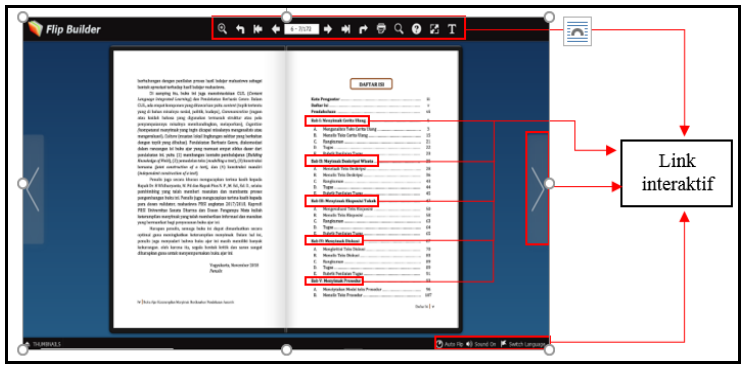

Gambar 6.Tautan Interaktif dalam Buku Ajar

\section{Penilaian Ahli}

Penilaian ahli dilakukan untuk mengetahui kelayakan produk penelitian yang telah dikembangkan. Dalam hal ini, Sugiyono (2019) memaparkan bahwa desain produk yang telah diciptakan tidak bisa langsung diujicobakan kepada pengguna tetapi harus dulu dibuat menjadi barang. Hal ini mengisyaratkan bahwa produk penelitian yang dikembangkan perlu ditinjau kembali dan dinilai oleh ahli untuk mendapatkan hasil yang maksimal sebelum uji coba kepada pengguna. Hal ini telah dilakukan oleh beberapa peneliti sebelumnya (Arsanti, 2018; Erika, 2019; Mulyaningtyas, 2020; Mursyid \& Amaliah, 2019). Tujuannya agar produk yang dirancang layak untuk berikan kepada pengguna.

Adapun produk penelitian pengembangan ini dinilai oleh ahli isi pembelajaran menyimak, dan ahli media pembelajaran. Penilaian produk oleh pembelajaran menyimak terdiri dari aspek isi, aspek penyajian, dan aspek kebahasaan, sedangkan penilaian produk ahli media terdiri dari aspek tampilan buku ajar, dan aspek kelayakan multimedia. Teknik analisis data yang digunakan dalam merepresentasikan penilaian ahli adalah teknik Teknik Weight Mean Score (WMS). Teknik ini digunakan untuk mendapatkan gambaran tentang kecenderungan rata-rata dari masing-masing variabel penelitian (Sudjana, 2005). Selain itu, perhitungan WMS dilakukan untuk mengetahui kedudukan setiap indikator atau item. Pada tahap ini, teknis WMS digunakan untuk mendapatkan hasil penilaian ahli isi dan ahli media terhadap semua aspek yang dinilai.

\section{A. Penilaian Ahli Isi Pembelajaran Keterampilan Menyimak}

Penilaian aspek isi buku ajar keterampilan menyimak bertujuan untuk mengetahui seberapa layak isi buku ajar yang dikembangkan, sehingga dapat digunakan mahasiswa sebagai buku pegangan dalam mengikuti pembelajaran keterampilan menyimak. Penilaian aspek isi ini terdiri dari beberapa indikator yaitu ketepatan capaian pembelajaran, ketepatan capaian pembelajaran dengan indikator, ketepatan materi ajar, ketepatan tugas, dan ketepatan penilaian. Pada Tabel 2 merupakan hasil penilaian ahli pada aspek isi buku ajar. 
Tabel 2

Hasil Penilaian Ahli pada Aspek Isi Buku Ajar

\begin{tabular}{|c|c|c|}
\hline No & Aspek yang dinilai & Skor \\
\hline I & $\begin{array}{l}\text { Capaian pembelajaran aspek pengetahuan memuat tingkatan kognitif dalam taksonomi Bloom (revisi } \\
\text { Anderson dan Krathwohl). }\end{array}$ & 4 \\
\hline 2 & $\begin{array}{l}\text { Capaian pembelajaran aspek keterampilan memuat tingkatan keterampilan abstrak dalam taksonomi } \\
\text { Dyers. }\end{array}$ & 4 \\
\hline 3 & Capaian pembelajaran aspek sikap memuat tingkatan afektif dalam taksonomi Krathwohl. & 4 \\
\hline 4 & Capaian pembelajaran sampai pada tingkat berpikir tingkat tinggi. & 3 \\
\hline 5 & Capaian pembelajaran sesuai dengan Capaian Pembelajaran Lulusan Prodi PBSI. & 3 \\
\hline 6 & $\begin{array}{l}\text { Deskripsi indikator pengetahuan sesuai dengan KKO dalam taksonomi Bloom (revisi Anderson dan } \\
\text { Krathwohl). }\end{array}$ & 4 \\
\hline 7 & Deskripsi indikator keterampilan sesuai dengan KKO dalam taksonomi keterampilan abstrak Dyer. & 4 \\
\hline 8 & Deskripsi indikator sikap sesuai dengan KKO dalam taksonomi afektif Krathwohl. & 4 \\
\hline 9 & Deskripsi indikator dapat mengukur capaian pembelajaran. & 3 \\
\hline 10 & Materi ajar sesuai dengan capaian pembelajaran dan indikator. & 4 \\
\hline II & Materi ajar memuat pengetahuan faktual, konseptual, prosedur, dan metakognisi. & 4 \\
\hline $\mathrm{I} 2$ & Materi ajar menggunakan pedagogi berbasis genre. & 3 \\
\hline $\mathrm{I3}$ & Konsep atau teori menggunakan sumber yang dapat dipercaya. & 3 \\
\hline $\mathrm{I} 4$ & Materi relevan dengan kehidupan sehari-hari. & 4 \\
\hline I5 & Teks yang digunakan sesuai dengan sumber aslinya. & 4 \\
\hline 16 & Materi pembelajaran memuat nilai-nilai budaya. & 4 \\
\hline $\mathrm{I7}$ & Tugas yang diberikan sesuai dengan capaian dan indikator pembelajaran. & 4 \\
\hline 18 & Petunjuk tugas mudah dipahami. & 4 \\
\hline 19 & Audio yang digunakan dalam tugas relevan dengan materi dan indikator. & 3 \\
\hline 20 & Video yang digunakan dalam tugas relevan dengan materi dan indikator. & 4 \\
\hline $2 \mathrm{I}$ & Terdapat variasi tugas (kinerja, proyek) & 4 \\
\hline 22 & Tugas yang diberikan meningkatkan keterampilan berbahasa. & 3 \\
\hline 23 & Rubrik penilaian sesuai dengan capaian dan indikator. & 3 \\
\hline 24 & Bentuk penilaian sesuai dengan tugas yang diberikan. & 3 \\
\hline 25 & Bentuk penilaian bervariasi & 4 \\
\hline 26 & Rubrik penilaian menggunakan rubrik holistik untuk mengukur capaian pembelajaran. & 4 \\
\hline 27 & Kriteria penilaian rubrik holistik dipaparkan secara rinci. & 3 \\
\hline 28 & Rubrik penilaian menggunakan rubrik analitik untuk mengukur capaian pembelajaran. & 4 \\
\hline \multirow[t]{3}{*}{29} & Kriteria penilaian rubrik analitik dipaparkan secara rinci. & 4 \\
\hline & Total skor & 106 \\
\hline & Rata-rata & 3,65 \\
\hline
\end{tabular}

Data penilaian ahli pada Tabel 2 menunjukkan bahwa aspek kelayakan isi buku ajar memiliki total skor 106 dengan rata-rata penilaian skor 3,65 dalam konvensi skala 4. Dalam penilaian isi produk, terdapat 19 butir item yang mendapat nilai 4 dengan kategori sangat baik dan IO butir item dengan kategori "baik". Berdasarkan penilaian ini, peneliti dapat menyimpulkan bahwa isi produk penelitian yang dikembangkan layak untuk digunakan dan diujicobakan kepada mahasiswa.

Penilaian ahli isi terhadap produk penelitian juga mengarah pada aspek penyajian buku ajar. Penilaian aspek penyajian bertujuan untuk mengetahui kesesuaian dan kelengkapan penyajian isi buku ajar yang dikembangkan. Adapun Penilaian aspek kelayakan penyajian ini mencakup dua indikator penilaian yaitu teknik penyajian dan kelengkapan penyajian dengan total enam butir pernyataan. Pada Tabel 3 merupakan hasil penilaian ahli pada aspek penyajian buku ajar. 
Tabel 3

Hasil Penilaian Ahli pada Aspek Penyajian

\begin{tabular}{|c|c|c|}
\hline No & Aspek yang Dinilai & Skor \\
\hline I & Buku ajar disusun dengan runtut sesuai dengan anatomi buku ajar perguruan tinggi. & 3 \\
\hline 2 & Sistematika isi buku ajar disusun secara konsisten pada setiap bab. & 4 \\
\hline 3 & Tabel, bagan, dan gambar disajikan dengan tepat. & 4 \\
\hline 4 & $\begin{array}{l}\text { Komponen bagian awal buku disajikan dengan lengkap (halaman, judul, kata pengantar, petunjuk umum, } \\
\text { deskripsi capaian akhir pembelajaran, daftar isi). }\end{array}$ & 4 \\
\hline 5 & $\begin{array}{l}\text { Komponen bagian isi buku ajar disajikan dengan lengkap (capaian pembelajaran, indikator, pengantar bab, } \\
\text { materi, tugas, rangkuman, dan rubrik penilaian). }\end{array}$ & 4 \\
\hline \multirow[t]{3}{*}{6} & $\begin{array}{l}\text { Komponen bagian akhir buku disajikan dengan lengkap (glosarium, daftar pustaka, sumber dari internet, } \\
\text { profil penulis). }\end{array}$ & 4 \\
\hline & Total skor & 23 \\
\hline & Rata-rata & 3,83 \\
\hline
\end{tabular}

Data penilaian ahli pada Tabel 3 menunjukkan bahwa aspek kelayakan sajian buku ajar memiliki total skor 23 dengan rata-rata penilaian skor 3,83 dalam konvensi skala 4. Penilaian dalam penyajian buku ajar mendapat skor 4 dengan kategori sangat baik untuk 5 butir item, dan nilai 3 dengan kategori baik untuk I butir item. Berdasarkan data ini, peneliti dapat menyimpulkan bahwa penyajian buku ajar layak digunakan dan diujicobakan kepada mahasiswa.

Selain penilaian pada aspek kelayakan isi, dan penyajian, peneliti juga meminta penilaian ahli pada aspek kelayakan bahasa yang digunakan dalam buku ajar. Penilaian ahli pada aspek kebahasaan mencangkup keseluruhan penggunaan bahasa yang terdapat dalam buku ajar yang dikembangkan peneliti seperti gaya penyampaian, ejaan dan tata bahasa. Penilaian ahli aspek kebahasaan ini terdiri dari lima butir pernyataan dengan dua indikator penilaian yaitu mengenai gaya penyampaian komunikatif, serta ejaan dan tata bahasa. Pada Tabel 4 merupakan hasil penilaian ahli pada aspek kebahasaan.

Tabel 4

Hasil Penilaian Ahli pada Aspek Kebahasaan

\begin{tabular}{|c|c|c|}
\hline No & Aspek yang Dinilai & Skor \\
\hline I & Bahasa yang digunakan mudah dipahami. & 4 \\
\hline 2 & Bahasa yang digunakan interaktif. & 4 \\
\hline 3 & Penggunaan ejaan sudah sesuai dengan Pedoman Umum Ejaan Bahasa Indonesia (PUEBI). & 3 \\
\hline 4 & Penulisan menggunakan kalimat efektif. & 3 \\
\hline \multirow[t]{3}{*}{5} & Adanya unsur kohesi dan koherensi pada antarkalimat maupun antarparagraf. & 3 \\
\hline & & 17 \\
\hline & & 3,4 \\
\hline
\end{tabular}

Data penilaian ahli pada Tabel 4 menunjukkan bahwa aspek kelayakan bahasa buku ajar memiliki total skor I7 dengan rata-rata skor 3,4 dalam konvensi skala 4 . Dalam penilaian ini, 2 butir item mendapat nilai 4 dengan kategori sangat baik dan 3 butir item mendapat nilai 3 dengan kategori baik. Berdasarkan data ini, peneliti dapat menyimpulkan bahwa hasil penilaian ahli terhadap aspek kebahasaan dalam buku ajar sangat baik dengan beberapa catatan revisi terkait penulisan ejaan.

Dalam rangka memperoleh hasil penilaian keseluruhan, peneliti merekapitulasi hasil penilaian ahli isi terhadap ketiga aspek di atas. Pada Tabel 5 merupakan hasil rekapitulasi dari ketiga aspek yang dinilai.

Tabel 5

Rekapitulasi Penilaian Ahli Pembelajaran Keterampilan Menyimak

\begin{tabular}{|c|c|c|c|}
\hline No & Aspek & Rerata & Kategori \\
\hline I & Aspek isi & 3,65 & Sangat baik \\
\hline 2 & Aspek penyajian & 3,84 & Sangat baik \\
\hline 3 & Aspek kebahasaan & 3,4 & Sangat baik \\
\hline & Total & 3,62 & Sangat baik \\
\hline
\end{tabular}

Handrianus Dwianot Momang, Pengembangan model buku ajar digital keterampilan menyimak berdasarkan pendekatan autentik 
Berdasarkan Tabel 5 dapat disimpulkan bahwa isi produk buku ajar masuk dalam kategori sangat baik dalam skala 4 yaitu dengan total rerata mencapai 3,62. Hal ini menunjukkan bahwa aspek isi, penyajian dan kebahasaan dalam buku ajar sudah layak untuk digunakan oleh mahasiswa. Meskipun demikian, ada beberapa masukan ahli yang perlu direvisi oleh peneliti yakni terkait kesalahan penulisan ejaan seperti penggunaan huruf, tanda baca dan kesalahan pengetikan (tipo)

\section{B. Penilaian Ahli Media Pembelajaran}

Produk buku ajar yang telah dikembangkan juga dinilai oleh ahli media. Dalam hal ini, ada dua hal yang nilai oleh ahli media yakni terkait aspek tampilan, dan aspek media pembelajaran yang digunakan. Penilaian aspek tampilan buku ajar cetak bertujuan untuk mengetahui kelayakan, dan kesesuaian tampilan buku ajar. Adapun penilaian aspek tampilan buku ajar ini mencakup ukuran fisik buku ajar, desain sampul, dan desain isi buku ajar. Pada Tabel 6 merupakan hasil penilaian ahli pada aspek kelayakan tampilan buku ajar yang dikembangkan peneliti.

Tabel 6

Hasil Penilaian Ahli pada Aspek Tampilan Buku Ajar

\begin{tabular}{clc}
\hline No & \multicolumn{1}{c}{ Aspek yang Dinilai } & Skor \\
\hline I & Ukuran fisik buku sesuai dengan standar ISO & 4 \\
2 & Ukuran fisik buku praktis digunakan mahasiswa. & 4 \\
3 & Tampilan sampul depan, punggung, dan belakang memiliki kesatuan (unity). & 4 \\
4 & Ukuran dan tata letak judul buku, pengarang, dan gambar proporsional. & 4 \\
5 & Ukuran dan bentuk huruf sudah sesuai. & 4 \\
6 & Warna huruf kontras sehingga mudah dibaca. & 4 \\
7 & Gambar pada sampul buku menggambarkan isi buku. & 4 \\
8 & Komposisi warna sampul buku ajar sesuai. & 4 \\
9 & Gambar pada sampul buku mendeskripsikan situasi yang nyata. & 3 \\
I0 & Tata letak isi buku konsisten. & 3 \\
II & Margin tiap halaman proporsional. & 4 \\
I2 & Penempatan judul, capaian pembelajaran, indikator, pengantar, materi, ilustrasi, kegiatan, tugas, dan & 4 \\
& rubrik penilaian sudah konsisten. & 4 \\
I3 & Pemilihan bentuk huruf tepat. & 4 \\
I4 & Gambar yang digunakan relevan dengan materi pembelajaran. & 4 \\
I5 & Gambar aktivitas yang digunakan dalam buku ajar cetak sesuai dengan bahan simakan yang terdapat \\
& dalam media pembelajaran & Total skor \\
I6 & Komposisi warna isi buku ajar konsisten. & 62 \\
\hline & $\quad$ Rata-rata \\
\hline
\end{tabular}

Data penilaian ahli media pada Tabel 6 menunjukkan bahwa aspek kelayakan tampilan buku ajar memiliki total skor 62 dengan rata-rata skor 3,87 dalam konvensi skala 4. Hasil penilaian menunjukkan bahwa I4 butir item mendapat skor 4 dengan kategori sangat baik dan 2 butir item mendapat skor 3 dengan kategori baik. Berdasarkan penilaian ini, peneliti dapat menyimpulkan bahwa hasil penilaian ahli media terhadap aspek tampilan buku ajar sangat baik dan layak digunakan pada tahap selanjutnya.

Di samping itu, peneliti juga meminta penilaian ahli media pada aspek kelayakan media pembelajaran yang digunakan pada produk buku ajar digital keterampilan menyimak. Tujuannya untuk mengetahui kelayakan penggunaan media dalam bentuk buku ajar digital. Adapun penilaian aspek media ini mencakup aspek pemakaian, dan aspek kualitas tampilan. Pada Tabel 7 merupakan hasil penilaian ahli pada aspek media yang digunakan. 
Tabel 7

Hasil Penilaian Ahli pada Aspek Tampilan Buku Ajar

\begin{tabular}{clc}
\hline No & \multicolumn{1}{c}{ Aspek yang dinilai } & Skor \\
\hline I & Media pembelajaran dapat diinstalasi dengan mudah. & 4 \\
2 & Petunjuk (navigasi) media pembelajaran dikontrol dengan mudah. & 4 \\
3 & Perpindahan slide tidak lambat. & 3 \\
4 & Slide buku dapat dikontrol dengan mudah. & 3 \\
5 & Audio dapat dikontrol dengan mudah. & 4 \\
6 & Video dapat dikontrol dengan mudah. & 4 \\
7 & Kualitas tampilan layar menarik. & 4 \\
8 & Kualitas gambar sangat jelas. & 4 \\
9 & Kualitas audio sangat jelas. & 4 \\
I0 & Kualitas video sangat jelas. & 4 \\
& & Total skor \\
\hline
\end{tabular}

Data penilaian ahli media pada Tabel 7 menunjukkan bahwa aspek media pembelajaran memiliki total skor 38 dengan rata-rata skor 3,8 dalam konvensi skala 4. Hasil penilaian menunjukkan bahwa 8 butir item mendapat skor 4 dengan kategori sangat baik dan 2 butir nomor mendapat skor 3 dengan kategori baik. Berdasarkan hasil penilaian ini, peneliti dapat menyimpulkan bahwa aspek media yang digunakan dalam buku ajar termasuk dalam kategori sangat baik dan layak digunakan.

Sama halnya dengan penilaian ahli isi, dalam rangka memperoleh hasil penilaian keseluruhan dari ahli media, peneliti membuat rekapitulasi untuk kedua aspek yang dinilai. Pada Tabel 8 merupakan hasil rekapitulasinya.

Tabel 8

Rekapitulasi Penilaian Ahli Media

\begin{tabular}{|c|c|c|c|}
\hline No & Aspek & Rerata & Kategori \\
\hline I & Aspek tampilan & 3,87 & Sangat baik \\
\hline 2 & Aspek multimedia & 3,8 & Sangat baik \\
\hline & Total & 3,83 & Sangat baik \\
\hline
\end{tabular}

Berdasarkan hasil rekapitulasi penilaian ahli media, dapat disimpulkan bahwa produk media buku ajar digital yang dikembangkan "sangat baik" dengan total rerata mencapai 3,83 dalam skala 4 . Hal ini menunjukkan bahwa dari aspek tampilan, dan media dalam produk sudah dapat dikatakan layak untuk digunakan dan diujicobakan kepada mahasiswa. Meskipun demikian, ahli media memberikan masukan sebagai bahan revisi mengenai kontrol audio. Hal ini karena kontrol audio yang terdapat dalam buku ajar dikontrol dengan manual ketika ingin memulai dan mengakhiri kegiatan menyimak. Ahli media menyarankan kontrol audio dirancang otomatis ketika membuka halaman baru. Masukan ini kemudian dijadikan bahan revisi untuk menyempurnakan produk penelitian ini.

\section{Revisi Produk Berdasarkan Penilaian Ahli}

Revisi produk pada tahap ini dilakukan berdasarkan masukan, dan saran dari ahli. Tujuannya untuk memperbaiki beberapa hal yang kurang atau tidak sesuai dalam produk penelitian (Sugiyono, 2019). Revisi produk pasca penilaian ahli dalam penelitian pengembangan umumnya sudah banyak dilakukan seperti penelitian dari (Arsanti, 2018; Mulyaningtyas, 2020; Mursyid \& Amaliah, 2019) dengan tujuan yang sama yakni mengarah pada proses perbaikan produk awal yang dikembangkan sebelum digunakan pada tahap selanjutnya.

Adapun revisi berdasarkan penilaian ahli terdiri dari kesalahan penulisan ejaan dan penyesuaian kontrol audio pada produk yang dikembangkan. Kesalahan penulisan ejaan terkait penggunaan huruf, tanda baca dan kesalahan pengetikan. Kesalahan penulisan ejaan umumnya terdapat pada penulisan kata "anda" yang seharusnya ditulis "Anda", penempatan tanda koma, dan kesalahan pengetikan seperti 
pada kata "system, dan indicator". Kesalahan-kesalahan ini kemudian direvisi peneliti sesuai identifikasi kesalahan yang terdapat pada produk buku ajar digital yang dikembangkan.

Selain itu, revisi produk juga pada kontrol audio simakan. Pada rancangan produk awal, kontrol audio dalam penggunaanya digunakan dengan cara menekan simbol audio dalam produk untuk memulai dan mengakhiri bahan simakan. Setelah proses revisi berdasarkan masukan ahli, kontrol audio kemudian diatur kembali agar ketika membuka halaman baru, audio simakan memulai secara otomatis dan akan berakhir ketika pengguna melanjutkan pada halaman selanjutnya.

\section{Uji Coba Lapangan}

Tahap ini merupakan implementasi dari tahap uji coba lapangan utama model Borg dan Ball (Borg \& Gall, 1983). Pada dasarnya uji coba lapangan ini terbatas yang diikuti oleh 57 mahasiswa. Uji coba lapangan ini dilakukan dengan cara melakukan simulasi pembelajaran sesuai dengan beberapa kegiatan yang telah dirancang sebelumnya dalam buku ajar dan diakhiri dengan penyebaran angket untuk mendapatkan penilaian mahasiswa terhadap produk yang dikembangkan. Uji coba lapangan dalam konteks ini hanya terbatas pada bentuk penilaian mahasiswa sebagai pengguna terhadap produk buku ajar. Uji coba lapangan ini tidak sampai pada fase eksperimen karena keterbatasan waktu dan diskusi peneliti. Adapun uji coba lapangan ini untuk mendapatkan penilaian mahasiswa terkait aspek tampilan, aspek penyajian dan aspek manfaat dari produk yang dikembangkan.

Pada aspek tampilan, terdapat tiga indikator yang menjadi penilaian produk. Tiga indikator yang dimaksud antara lain tampilan sampul buku ajar, tampilan isi buku, dan tampilan media pembelajaran. Indikator-indikator penilaian ini secara keseluruhan terdiri dari sepuluh pernyataan. Tabel 9 menunjukkan data dan hasil penilaian mahasiswa terhadap aspek tampilan produk.

Tabel 9

Hasil penilaian mahasiswa pada aspek tampilan

\begin{tabular}{|c|c|c|c|c|}
\hline No. & Butir pernyataan & Total skor & Rata-rata & Kategori \\
\hline $\mathrm{I}$ & Tampilan sampul buku menarik. & 194 & 3,4 & Sangat baik \\
\hline 2 & Gambar sampul buku sesuai dengan isi buku. & 196 & 3,44 & Sangat baik \\
\hline 3 & Ukuran dan jenis huruf tepat. & 198 & 3,47 & Sangat Baik \\
\hline 4 & Komposisi warna sampul buku sesuai. & I9I & 3,35 & Sangat Baik \\
\hline 5 & Tampilan isi buku menarik. & 193 & 3,39 & Sangat Baik \\
\hline 6 & Gambar memiliki kualitas yang baik. & 192 & 3,37 & Sangat Baik \\
\hline 7 & Huruf mudah dibaca. & 201 & 3,53 & Sangat Baik \\
\hline 8 & Komposisi warna pada isi buku konsisten. & 194 & 3,4 & Sangat Baik \\
\hline 9 & Tampilan media pembelajaran menarik. & 196 & 3,44 & Sangat Baik \\
\hline \multirow[t]{2}{*}{ I0 } & Tampilan navigasi media menarik & $\mathrm{I} 85$ & 3,25 & Baik \\
\hline & Total & I940 & 3,4 & Sangat Baik \\
\hline
\end{tabular}

Data analisis pada Tabel 9 dapat disimpulkan bahwa keseluruhan penilaian mahasiswa pada aspek tampilan mendapat kategori "Sangat baik". Hal ini ditunjukkan dengan perolehan rata-rata skor yang diberikan mahasiswa keseluruhan pada aspek tampilan dengan nilai 3,4 dengan kategori sangat baik. Meskipun mendapat kategori sangat baik, beberapa mahasiswa memberikan masukan dan saran mengenai aspek tampilan pada produk. Pertama, 2 mahasiswa meminta agar gambar subjek yang digunakan pada sampul buku diganti dengan subjek yang lebih menarik. Hal ini karena gambar manusia yang terkesan lebih tua dari segi umur. Kedua, 4 mahasiswa meminta agar warna isi buku ajar bervariasi dan tidak terpaku pada satu warna saja. Komposisi warna pada isi buku ajar lebih cenderung mengarah pada warna jingga, sehingga mereka merekomendasi agar warna dalam isi buku ajar dapat dikolaborasikan dengan warna lainnya agar lebih menarik. Masukan dan saran dari mahasiswa ini kemudian dipertimbangkan sebagai masukan dan bahan revisi.

Penilaian mahasiswa terhadap produk penelitian juga pada aspek penyajian. Pada aspek penyajian, ada empat indikator yang menjadi penilaian. Empat indikator ini antara lain mengenai 
sistematika penulisan, sajian materi pembelajaran, sajian tugas, dan sajian rubrik penilaian. Indikatorindikator penilaian pada aspek ini secara keseluruhan terdiri dari I2 butir pernyataan. Pada Tabel I0 merupakan data penilaian mahasiswa terhadap aspek penyajian produk

Tabel 10

Hasil Penilaian Mahasiswa pada Aspek Penyajian

\begin{tabular}{|c|c|c|c|c|}
\hline No. & Butir pernyataan & Total Skor & Rata-rata & Kategori \\
\hline I & Sistematika penulisan tiap bab konsisten. & 198 & 3.47 & Sangat baik \\
\hline 2 & Sistematika tiap bab lengkap. & 198 & 3.47 & Sangat baik \\
\hline 3 & Materi yang disajikan mudah dipahami. & 194 & 3.4 & Sangat Baik \\
\hline 4 & $\begin{array}{l}\text { Gambar, audio, dan video yang digunakan sesuai dengan } \\
\text { materi. }\end{array}$ & 203 & 3.56 & Sangat Baik \\
\hline 5 & Materi meningkatkan Keterampilan Menyimak. & 204 & 3.58 & Sangat Baik \\
\hline 6 & $\begin{array}{l}\text { Materi pembelajaran memuat nilai-nilai budaya yang } \\
\text { dapat dipelajari. }\end{array}$ & 190 & 3.33 & Sangat Baik \\
\hline 7 & Petunjuk tugas mudah dipahami. & 190 & 3.33 & Sangat Baik \\
\hline 8 & Tugas sesuai dengan materi pembelajaran. & 201 & 3.53 & Sangat Baik \\
\hline 9 & Tugas meningkatkan keterampilan berbahasa. & 198 & 3.47 & Sangat Baik \\
\hline I0 & Kriteria rubrik penilaian mudah dipahami. & I88 & 3.3 & Sangat Baik \\
\hline II & $\begin{array}{l}\text { Kriteria rubrik penilaian sesuai dengan aktivitas dan tugas } \\
\text { yang dikerjakan. }\end{array}$ & 190 & 3.33 & Sangat Baik \\
\hline \multirow[t]{2}{*}{$\mathrm{I} 2$} & $\begin{array}{l}\text { Rubrik penilaian mengarahkan saya dalam melaksanakan } \\
\text { tugas. }\end{array}$ & 188 & 3.3 & Sangat Baik \\
\hline & Rata-rata & & 3,42 & Sangat Baik \\
\hline
\end{tabular}

Berdasarkan data pada Tabel I0, dapat disimpulkan bahwa keseluruhan penilaian mahasiswa pada aspek penyajian mendapat kategori "Sangat baik". Hal ini ditunjukkan dengan perolehan rata-rata skor yang diberikan mahasiswa pada keseluruhan aspek tampilan dengan nilai 3,42 dengan kategori sangat baik. Pada aspek penyajian ini tidak ada butir pernyataan yang direvisi karena tiap butir pernyataan mendapat kategori "sangat baik", dan tidak ada saran atau masukan tambahan dari mahasiswa.

Sama halnya dengan aspek tampilan dan penyajian, peneliti juga meminta penilaian mahasiswa pada aspek manfaat. Aspek manfaat ini ditujukan untuk melihat kebermanfaatan produk penelitian yang dikembangkan peneliti. Pada aspek ini, terdapat dua indikator yang menjadi penilaian. Dua indikator ini antara lain mengenai kemudahan belajar, dan peningkatan motivasi belajar. Tiap indikator masingmasing terdiri dari 4 butir pernyataan. Pada Tabel II merupakan hasil penilaian mahasiswa pada aspek manfaat. 
Tabel II

Hasil Penilaian Mahasiswa pada Aspek Manfaat

\begin{tabular}{|c|c|c|c|c|}
\hline No & Butir pernyataan & Total Skor & Rata-rata & Kategori \\
\hline I & $\begin{array}{l}\text { Buku ajar membantu saya dalam meningkatkan } \\
\text { keterampilan menyimak. }\end{array}$ & 200 & $3,5 \mathrm{I}$ & Sangat baik \\
\hline 2 & $\begin{array}{l}\text { Buku ajar membantu saya dalam belajar terbimbing } \\
\text { maupun mandiri. }\end{array}$ & 200 & $3,5 \mathrm{I}$ & Sangat baik \\
\hline 3 & $\begin{array}{l}\text { Media pembelajaran membantu saya dalam meningkatkan } \\
\text { keterampilan menyimak. }\end{array}$ & 206 & $3.6 \mathrm{I}$ & Sangat Baik \\
\hline 4 & $\begin{array}{l}\text { Gaya belajar yang saya miliki terakomodasi dalam media } \\
\text { pembelajaran. }\end{array}$ & I8I & 3.18 & Baik \\
\hline 5 & $\begin{array}{l}\text { Saya lebih termotivasi untuk meningkatkan keterampilan } \\
\text { menyimak. }\end{array}$ & 192 & 3.37 & Sangat Baik \\
\hline 6 & $\begin{array}{l}\text { Saya lebih termotivasi belajar dengan pemodelan teks } \\
\text { (struktur dan ciri kebahasaan). }\end{array}$ & I78 & 3.I I & Baik \\
\hline 7 & $\begin{array}{l}\text { Saya termotivasi belajar dengan media pembelajaran yang } \\
\text { disediakan. }\end{array}$ & 195 & 3.42 & Sangat Baik \\
\hline \multirow[t]{2}{*}{8} & $\begin{array}{l}\text { Catatan budaya membantu saya dalam memahami konteks } \\
\text { situasi yang nyata. }\end{array}$ & 203 & 3.56 & Sangat Baik \\
\hline & Rata-rata & I.5555 & 3,4 & Sangat Baik \\
\hline
\end{tabular}

Berdasarkan data pada Tabel II dapat disimpulkan bahwa keseluruhan penilaian mahasiswa pada aspek penyajian mendapat kategori "Sangat baik". Hal ini ditunjukkan dengan perolehan rata-rata skor yang diberikan mahasiswa pada keseluruhan aspek tampilan dengan nilai 3,4 dengan kategori sangat baik. Pada aspek manfaat tiap butir pernyataan mendapat kategori "Sangat Baik" dan "Baik" serta tidak ada saran dan masukan tambahan mengenai aspek manfaat ini.

Berdasarkan hasil penilaian mahasiswa terhadap aspek tampilan, penyajian dan manfaat, peneliti membuat rekapitulasi untuk mendapatkan hasil penilaian secara keseluruhan. Pada Tabel 12 merupakan hasil rekapitulasi penilaian mahasiswa pada ketiga aspek yang dinilai.

Tabel I2

Rekapitulasi Penilaian Produk Mahasiswa

\begin{tabular}{|c|c|c|c|}
\hline No & Aspek & Rerata & Kategori \\
\hline $\mathrm{I}$ & Aspek Tampilan & 3,4 & Sangat baik \\
\hline 2 & Aspek Penyajian & 3,42 & Sangat Baik \\
\hline \multirow[t]{2}{*}{3} & Aspek Manfaat & 3,4 & Sangat baik \\
\hline & & 3,4 & Sangat baik \\
\hline
\end{tabular}

Data hasil rekapitulasi penilaian mahasiswa terhadap produk dapat dikatakan masuk dalam kategori "Sangat Baik" dengan total skor mencapai 3,4 dalam skala 4. Adapun beberapa masukan dari mahasiswa terkait tampilan produk ini yakni tampilan ilustrasi model sampul buku, dan variasi warna yang terdapat pada desain isi buku ajar. Masukan mahasiswa ini kemudian dijadikan sebagai bahan pertimbangan revisi produk final.

\section{Revisi Produk Final}

Pada tahap ini, revisi dilakukan sebagaimana saran dan masukan yang diberikan pada tahap uji coba lapangan (Borg \& Gall, I983). Revisi produk final dalam penelitian pengembangan ini merujuk pada masukan dan saran yang diberikan oleh mahasiswa selaku pengguna produk. Dalam hal ini, masukan yang diberikan terkait gambar dan warna sampul dan warna pada isi produk. Sama halnya dengan salah satu bentuk revisi yang dilakukan oleh Arsanti (2018) terkait desain layout dalam produk yang berpengaruh pada substansi isi buku. Adapun masukan yang diberikan oleh pengguna tidak ditindaklanjuti dalam proses revisi produk final. Hal ini karena hanya terdapat 2-4 mahasiswa saja yang memberi rekomendasi terkait hal ini sedangkan mayoritas lainnya memberi komentar yang baik. Selain 
itu, berdasarkan pertimbangan, dan diskusi, masukan beberapa mahasiswa ini dianggap tidak perlu dilakukan karena dapat berpengaruh pada konsistensi tampilan yang sudah dinilai dengan baik oleh ahli, dan mayoritas pengguna produk.

\section{SIMPULAN}

Model pengembangan buku ajar keterampilan menyimak berbasis pendekatan autentik dikembangkan melalui model pengembangan hasil modifikasi yang terdiri dari (I) analisis kebutuhan pembelajaran (2) desain produk, (3) penilaian ahli, (4) revisi berdasarkan hasil penilaian, (5) uji coba lapangan, (6) revisi produk final. Pada tahap analisis kebutuhan, peneliti mengidentifikasi kebutuhan pembelajaran keterampilan menyimak terkait kebutuhan buku acuan utama yang mengakomodasi tujuan pembelajaran, variasi materi dengan konten-konten simakan yang faktual dan menarik, serta bentuk tugas dan penilaian yang terstruktur dan jelas. Selain itu, pembelajaran keterampilan menyimak membutuhkan media pembelajaran yang menarik dan dapat diakses dengan mudah. Kebutuhankebutuhan ini kemudian dijadikan salah satu dasar pertimbangan dalam mengembangkan produk penelitian.

Pada tahap desain produk, peneliti mengembangkan produk berupa buku ajar yang dirancang dengan mengacu dan mempertimbangkan beberapa hal seperti kebutuhan pembelajaran, anatomi buku ajar, dan pendekatan autentik khususnya dalam penyajian bagian inti pembelajaran seperti tujuan, dan indikator pembelajaran, materi ajar, tugas, dan penilaian. Selain itu, desain produk penelitian juga mengadopsi siklus dalam pendekatan berbasis genre, dan 4C yang ditawarkan Coyle dalam CLIL. Setelah prototype awal selesai, peneliti menggunakan aplikasi flipbook maker untuk mendigitalisasi produk buku ajar dengan memaksimalkan pemerian bahan simakan yang sesuai dengan kebutuhan.

Produk buku ajar digital yang telah dirancang selanjutnya dinilai ahli. Pada tahap penilaian ahli, produk pengembangan ini dinilai oleh ahli isi pembelajaran dan ahli media. Hasil penilaian ahli isi pembelajaran keterampilan menyimak menunjukkan bahwa secara keseluruhan (isi, penyajian, dan bahasa) produk buku ajar digital yang dikembangkan masuk dalam kategori sangat baik dengan nilai rerata sebesar 3,62. Sama halnya dengan penilaian ahli media yang secara menyeluruh menunjukkan bahwa produk buku ajar yang dikembangkan berada dalam kategori sangat baik dengan rerata 3,83. Hasil penilaian ahli isi dan ahli media menunjukkan bahwa produk yang dikembangkan layak untuk digunakan.

Meskipun demikian, terdapat masukan dan saran dari ahli yang perlu direvisi dalam produk pengembangan ini. Pada tahap revisi ini, produk ditelaah dan ditinjau kembali berdasarkan masukan, dan saran ahli. Adapun masukan ahli isi terkait kesalahan penulisan ejaan seperti penggunaan huruf, tanda baca, dan kesalahan pengetikan, sedangkan ahli media menyarankan agar kontrol audio diatur kembali, sehingga lebih mudah digunakan. Masukan dan saran ini ditindaklanjuti untuk mendapatkan hasil yang maksimal. Produk yang telah direvisi juga ditinjau kembali oleh masing-masing ahli untuk mengonfirmasi kembali terkait masukan dan saran yang telah diberikan sebelumnya.

Produk buku ajar yang telah dinilai ahli selanjutnya diujicobakan pada mahasiswa untuk mendapatkan penilaian terkait aspek tampilan, penyajian dan manfaat. Hasil penilaian 57 mahasiswa yang mengikuti pembelajaran keterampilan menyimak menunjukkan bahwa produk buku ajar yang dikembangkan masuk dalam kategori sangat baik dengan rerata keseluruhan aspek mencapai 3,4 dalam skala 4. Adapun masukan beberapa mahasiswa yang menjadi bahan revisi produk akhir terkait penggunaan gambar dan warna dalam sampul dan isi buku. Meskipun demikian, tahap revisi produk berdasarkan uji coba lapangan tidak dilakukan karena dapat berdampak pada konsistensi tampilan yang sudah dinilai oleh dengan baik oleh ahli dan mayoritas pengguna produk.

Berdasarkan hasil yang diperoleh, produk penelitian ini dapat dikatakan layak dan dapat digunakan sebagai alternatif buku ajar dalam pembelajaran keterampilan menyimak. Produk buku ajar ini sekiranya memfasilitasi pengembangan kompetensi menyimak mahasiswa yang berkesinambungan, baik dalam kegiatan pembelajaran di kelas maupun pada lingkup kehidupan sehari-hari. Selain itu,

Handrianus Dwianot Momang, Pengembangan model buku ajar digital keterampilan menyimak berdasarkan pendekatan autentik 
konten-konten visual, audio, dan audiovisual dalam produk penelitian sekiranya mampu meningkatkan kepekaan mahasiswa dalam proses menyimak isu dan masalah yang terjadi di sekitar mereka.

Selanjutnya ada beberapa rekomendasi yang perlu dipertimbangkan, dan diperhatikan lebih lanjut khususnya oleh peneliti lanjutan. Rekomendasi yang dimaksud terkait (I) pengembangan produk sekiranya melibatkan peserta didik atau responden dari berbagai lembaga atau sekolah untuk mengakumulasi kebutuhan menyeluruh, sehingga produk yang diciptakan dapat disebarluaskan, (2) konten-konten dalam buku ajar sekiranya selalu diperbaharui sesuai dengan kebutuhan peserta didik nantinya, (3) proses penilaian ahli melibatkan banyak ahli sesuai bidang keahliannya masing-masing, (4) proses uji coba lapangan sekiranya dapat dilakukan hingga fase eksperimen demi meningkatkan kualitas produk yang dikembangkan, (5) buku ajar digital yang hendak dikembangkan sekiranya dapat diakses secara online menggunakan gawai sehingga praktis digunakan.

\section{UCAPAN TERIMA KASIH}

Peneliti ucapkan terima kasih kepada Yayasan Santu Paulus Ruteng yang telah mendanai penelitian ini serta khususnya kepada Bapak Dr. B. Widharyanto, M.Pd., dan Bapak Drs. Pius Nurwidasa P., M.Ed., Ed.D. selaku mentor yang telah membantu dan membimbing peneliti dalam menyelesaikan penelitian ini.

\section{DAFTAR PUSTAKA}

Abdulrahman, T., Basalama, N., \& Widodo, M. R. (2018). The impact of podcasts on efl students' listening comprehension. International Journal of Language Education, 2(2), 23-33. https://doi.org/I0.26858/ijole.v2i2.5878

Anderson, L. W., Krathwohl, D. R. D. R., \& Bloom, B. S. (200I). A taxonomy for learning, teaching, and assessing. New York: Longman.

Arifin, S., \& Kusrianto, A. (2009). Sukses menulis buku ajar dan referensi. Jakarta: Grasindo.

Arsanti, M. (2018). Pengembangan bahan ajar mata kuliah penulisan kreatif bermuatan nilai-nilai pendidikan karakter religius bagi mahasiswa Prodi PBSI, FKIP, Unissula. KREDO: Jurnal Ilmiah Bahasa dan Sastra, I(2), 7I-90. https://doi.org/I0.24I76/kredo.vIi2.2I07

Berardo, S. A. (2006). The use of authentic materials in the teaching of reading. The Reading Matrix: An International Online Journal, 6(2), 60-69. Retrived from https://readingmatrix.com/archives/archives_vol6_no2.html

Bloom, B. S., Krathwohl, D. R., \& Masia, B. B. (1956). Taxonomy of educational objectives. The classification of educational goals: Hanbook I. In Handbook I: Cognitive domain / by a committee of college anduniversity examiners: Benjamin S. Bloom, ed. ... et al.. - 1956. - $207 \mathrm{~s}$.

Borg, W., \& Gall, M. (1983). Educational research: An introduction 4th edition. New York: Longman.

Breidbach, S., \& Viebrock, B. (20I2). CLIL in Germany - Results from Recent Research in a Contested Field of Education. International CLIL Research Journal, I(4), 5-I6 Retrived from http://www.icrj.eu/I4/articleI.html

Cinganotto, L. (2016). CLIL in Italy: A general overview. Latin American Journal of Content \& Language Integrated Learning, 92), 374-400. https:/ / doi.org/I0.5294/lacli1.2016.9.2.6

Coyle, D., Hood, P., \& Marsh, D. (2010). Content and Language Integrated Learning. Cambridge: Cambridge University Press.

Dick, W., \& Carey, L. (1996). The systematic design of instruction. In Instructional Design: International Perspectives: Theory, Research, and Models (4th ed.). Harper Collins College Publishers.

Dirgeyasa, I. W. (2016). Genre-based approach: What and how to teach and to learn writing. English Language Teaching, 9(9), 45-5I. https://doi.org/I0.5539/elt.v9n9p45

Doludea, A., \& Nuraeni, L. (2018). Meningkatkan keteterampilan menyimak pada anak usia dini 5-6 tahun dengan metode bercerita melalui wayang kertas di TK Makedonia. Jurnal CERIA 
(Cerdas Energik Responsif Inovatif Adaptif), I(I), I-5. https://doi.org/I0.22460/ceria.vIiI

Dyer, J. H., Gregersen, H. B., \& Christensen, C. M. (20II). The innovator's DNA Mastering the five Skills of Disruptive Inovator. Boston: Harvard Business Press

Ellison, M. (2019). (Net)Working CLIL in Portugal. E-TEALS, $9(\mathrm{sI})$, 4-22. https://doi.org/I0.2478/eteals-2018-00I0

Erika, C. N. (2019). Pengembangan buku ajar bahasa Indonesia terintegrasi pendidikan karakter berdasarkan pendekatan komunikatif. Jurnal Pendidikan Bahasa dan Sastra, I9(2), 267-279. https://doi.org/IO.I7509/bs_jpbsp.vI9i2.24832

Eriyanti, R. W. (2018). Pengembangan bahan ajar keterampilan berbicara interaktif bagi mahasiswa. KEMBARA: Jurnal Keilmuan Bahasa, Sastra, dan Pengajarannya (e-Journal), 3(I), 98-I06. https://doi.org/I0.22219/kembara.vol3.noI

Ernalis, -, Syahruddin, D., \& Abidin, Y. (2016). Pengembangan model bahan ajar bahasa Indonesia berbasis model pembelajaran yang berorientasi pada pendidikan karakter. EduHumaniora/ Jurnal Pendidikan Dasar Kampus Cibiru, 5(I). I-II. https:/ / doi.org/I0.17509/eh.v5iI.2832

Friston, K. J., Sajid, N., Quiroga-Martinez, D. R., Parr, T., Price, C. J., \& Holmes, E. (2020). Active listening. Hearing Research Journal. 399(I), I-28. https://doi.org/I0.I0I6/j.heares.2020.107998

Gay, E., Djibat, B., \& Umahuk, S. (2018). Genre-based approach: Its integration to teach english grammar in constructing sentences. International Journal of Scientific and Technology Research, 7(I2), 262-266. Retrived from https://www.ijstr.org/research-paperpublishing.php?month $=\operatorname{dec} 2018$

Hamouda, A. (20II). Listening comprehension problems-voices from the classroom. Ejournal.Narotama.Ac.Id. II (june), 92-IOI Retrived from http://www.languageinindia.com/aug2012/arafatlisteningproblemsfinal.html

Itaristanti, I. (2016). Portofolio sebagai salah satu model penilaian otentik di SD/MI. Al Ibtida: Jurnal Pendidikan Guru MI, 3(2). 2I2-226. https:// doi.org/I0.24235/al.ibtida.snj.v3i2.904

Jacobson, E., Degener, S., \& Purcell-Gates, V. (2003). Creating authentic materials and activities for the adult literacy classroom: A handbook for practitioners. NCSALL.

Listiyaningsih, T. (2017). The Influence of listening english song to improve listening skill in listening class. Academica: Journal of Multidisciplinary Studies, I(I), 35-49. Retrived from http:// ejournal.iainsurakarta.ac.id/index.php/academica/article/view/60I

Lombardi, B. M. M., \& Oblinger, D. G. (2007). Authentic learning for the 2Ist century: An overview. Educause Learning Initiative, I(I), I-I2. Retrived from https:/ / library.educause.edu/resources/2007/I/authentic-learning-for-the-2I st-century-anoverview

Made Darmayanti, I. ayu. (2018). Pemanfaatan media youtube berita pendidikan dalam pembelajaran keterampilan menyimak. Prosiding Seminar Nasional V: Bahasa, Sastra, dan Pengajarannya. undiksa, Denpasar, 2018, I34-139

Mana, L. H. A., Yusandra, T. F., Atmazaki, A., \& Ramadhan, S. (2020). Pengembangan buku ajar keterampilan menyimak berbasis contextual teaching and learning. Jurnal Kependidikan: Penelitian Inovasi Pembelajaran, 4(I), I52-I64. https://doi.org/I0.2183I/jk.v4iI.I3594

Mishan, F. (2004). Designing authenticity into language learning materials. In Designing Authenticity into Language Learning Materials. Bristol: Intelect Ltd.

Mulyaningtyas, R. (2020). Pengembangan buku ajar mata kuliah media pembelajaran bahasa Indonesia untuk mahasiswa. Belajar bahasa: Jurnal Ilmiah Program Studi Pendidikan Bahasa dan Sastra Indonesia, 5(I), I5I-I60. https://doi.org/I0.32528/bb.v5iI.3070

Mursyid, M., \& Amaliah, Y. (2019). Pengembangan buku ajar mata kuliah bahasa Indonesia berbasis pembelajaran kooperatif untuk penguatan karakter mahasiswa Fakultas Tarbiyah dan Keguruan UIN STS Jambi. Didaktis: Jurnal Pendidikan dan Ilmu Pengetahuan, I9(I), 94-I02. 
https://doi.org/I0.3065I/didaktis.vI9iI.25I5

Niarti, N., Ruminto, N. E., \& Haenilah, E. Y. (2017). Pengembangan bahan ajar berbasis multimedia interaktif pada materi menyimak untuk siswa Kelas VI SD. Jurnal Pedagogi, 5(I), I-I7. Retrived from http://jurnal.fkip.unila.ac.id/index.php/pgsd/article/view/I I736

Nurani, R. Z., Nugraha, F., \& Sidik, G. S. (2018). Penggunaan media audio visual dalam pembelajaran menyimak dongeng di era digital. EduHumaniora/Jurnal Pendidikan Dasar Kampus Cibiru, IO(2), 78-84. https://doi.org/I0.I7509/eh.vI0i2.I0867

Nurgiyantoro, B. (2013). Model penilaian otentik dalam pembelajaran bahasa. Litera, IO2), I I4-I24. https://doi.org/I0.2I83I/1tr.vI0i2.I I57

Ornellas, A., Falkner, K., \& Edman Stålbrandt, E. (2019). Enhancing graduates' employability skills through authentic learning approaches. Higher Education, Skills and Work-Based Learning, Q(I), I07-I20. https://doi.org/IO.II08/HESWBL-04-2018-0049

Polio, C. (20I4). Using authentic materials in the beginning language classroom. Clear News, Michigan State University, I8(I), I-7. Retrived from http://clear.msu.edu/spring-20I4-usingauthentic-materials-in-the-beginning-language-classroom/

Prihatin, Y. (2017). Problematika keterampilan menyimak dalam pembelajaran bahasa Indonesia. $\begin{array}{llll}\text { Sastranesia, } & 5(3), & \text { R5-52. } & \text { Retrived }\end{array}$ https://ejournal.stkipjb.ac.id/index.php/sastra/article/view/757/544

Pujiatna, T., Rosmaya, E., \& Wahyuningsih, N. (2020). Pengembangan bahan ajar simak berorientas kearifan lokal untuk meningkatkan kemampuan literasi mahasiswa pada mata kuliah menyimak. Deiksis: Jurnal Pendidikan Bahasa dan Sastra Indonesia, 7(1), 9I-97. https://doi.org/I0.33603/deiksis.v7iI.2804

Puspitoningrum, E. (2015). Pengembangan bahan ajar menulis kembali dongeng untuk siswa SMP kelas VII. KEMBARA: Jurnal Keilmuan Bahasa, Sastra, dan Pengajarannya (e-journal), I(2), I52-I62. https:// doi.org/I0.22219/kembara.vIi2.2612

Rahmayantis, M. D. (2016). Pengembangan bahan ajar membaca indah puisi untuk siswa SMP kelas VII. KEMBARA: Jurnal Keilmuan Bahasa, Sastra, dan Pengajarannya (e-Journal), 2(I), 47-56. https://doi.org/I0.22219/kembara.v2iI.4043

Roach, K., Tilley, E., \& Mitchell, J. (2018). How authentic does authentic learning have to be? Higher Education Pedagogies, 3(I), 495-509. https://doi.org/I0.1080/23752696.2018.I462099

Rost, M. (2016). Teaching and researching listening: Third edition. Pearson Education Limited: United Kingdom.

Soerraya, A., \& Sriwulandari, Y. A. (2019). Media JMix untuk meningkatkan kemampuan menyimak pada pembelajaran matakuliah menyimak apresiatif-kreatif di IKIP Budi Utomo Malang. Paradigma: Jurnal Filsafat, Sains, Teknologi, dan Sosial Budaya, 25(2), 39-47. https://doi.org/I0.33503/paradigma.v25i2.570

Sudjana. (2005). Metode statistika. Bandung: Tarsito.

Sugiyono. (2019). Metode penelitian pendidikan. Bandung: Alfabeta.

Sugiyono, E. I. (20I4). Pengembangan bahan ajar menyimak berbasis multimedia interaktif dalam model belajar mandiri untuk sekolah menengah pertama. Seloka: Jurnal Pendidikan Bahasa dan Sastra Indonesia, 3(2), 83-89. $\quad$ Retrived from https://journal.unnes.ac.id/sju/index.php/seloka/article/view/66I9

Suryanto, E. (2016). Pengembangan materi ajar mata kuliah apresiasi drama melalui penggalian nilainilai pendidikan karakter naskah drama panembahan reso karya W.S. Rendra. Bahasa dan Seni: Jurnal Bahasa, Sastra, Seni dan Pengajarannya, 44 (2), 207-223. https://doi.org/10.17977/um015v44i22016p207

Tangkakarn, B., \& Gampper, C. (2020). The effects of reading-while-listening and listening-beforereading-while-listening on listening and vocabulary. International Journal of Instruction, I3(3), 789-804. https:/ / doi.org/I0.29333/iji.2020.13353a 
Tanrikulu, F. (2020). The effect of L2 listening texts adapted to the digital story on the listening lesson. Turkish Online Journal of Distance Education, 2I(I), I-I8. https://doi.org/IO.17718/TOJDE.674382

Tuan, L. T. (20I I). Teaching writing through genre-based approach. Theory and Practice in Language Studies, I(I I), I2I-36. https://doi.org/I0.4304/tpls.I.I I.I47I-I478

Vaughan, T. (2006). Multimedia: Making it work eighth edition. Terjemahan Theresia Arie Prabawati \& Agnes Heni Triyuliana. Yogyakarta: Andi.

Widharyanto, B. (2016). Autentisitas di dalam pembelajaran bahasa Indonesia. Seminar Nasional Bahasa dan Sastra Indonesia, I (Mengenang Kiprah J.S Badudu), I00-I09. https://www.researchgate.net/publication/323915678

Wiranty, W. (2019). Peningkatan keterampilan menyimak komprehensif dan kritis dengan metode resitasi pada mahasiswa. Edukasi: Jurnal Pendidikan, I7(I), II2-I20. https://doi.org/I0.3I57I/edukasi.vI7iI.I082

Worthington, D. L., \& Bodie, G. D. (2018). Defining listening: A historical, theoretical, and pragmatic assessment. In The Sourcebook of Listening Research: Methodology and Measures.

Yusantika, F. D., Suyitno, I., \& Furaidah, F. (2018). Pengaruh media audio dan audio visual terhadap kemampuan menyimak siswa kelas IV. Jurnal Pendidikan: Teori, Penelitian, dan Pengembangan, $\quad 3(2), \quad$ 25I-258. Retrived from http://journal.um.ac.id/index.php/jptpp/article/view/I0544 